\title{
Article
}

\section{Health and Wellbeing Benefits from Nature Experiences in Tropical Settings Depend on Strength of Connection to Nature}

\author{
Rachel R. Y. Oh ${ }^{1,2,3, * \mathbb{D}}$, Kelly S. Fielding ${ }^{4}$, Chia-Chen Chang ${ }^{5}$, Le T. P. Nghiem ${ }^{5}$, Claudia L. Y. Tan ${ }^{5}$, \\ Shimona A. Quazi ${ }^{6}$, Danielle F. Shanahan ${ }^{7}$, Kevin J. Gaston ${ }^{8}$, Roman L. Carrasco ${ }^{5}$ and Richard A. Fuller ${ }^{1}$ (D) \\ 1 Centre for Biodiversity and Conservation Sciences, School of Biological Sciences, University of Queensland, \\ Brisbane 4072, Australia; r.fuller@uq.edu.au \\ 2 Department of Ecosystem Services, Helmholtz Centre for Environmental Research (UFZ), \\ 04318 Leipzig, Germany \\ 3 German Centre for Integrative Biodiversity Research (iDiv) Halle-Jena-Leipzig, 04103 Leipzig, Germany \\ 4 School of Communication and Arts, University of Queensland, Brisbane 4072, Australia; k.fielding@uq.edu.au \\ 5 Department of Biological Sciences, National University of Singapore, Singapore 117558, Singapore; \\ chiajen.chang@gmail.com (C.-C.C.); nghphuongle@nus.edu.sg (L.T.P.N.); claudiatan_ly@u.nus.edu (C.L.Y.T.); \\ dbsctlr@nus.edu.sg (R.L.C.) \\ 6 National Parks Board, Singapore 259569, Singapore; Shimona_QUAZI@nparks.gov.sg \\ 7 Zealandia Centre for People and Nature, Wellington 6012, New Zealand; \\ danielle.shanahan@visitzealandia.com \\ 8 Environment \& Sustainability Institute, University of Exeter, Cornwall TR10 9FE, UK; K.J.Gaston@exeter.ac.uk \\ * Correspondence: r.oh@uq.edu.au
}

Citation: Oh, R.R.Y.; Fielding, K.S. Chang, C.-C.; Nghiem, L.T.P.; Tan, C.L.Y.; Quazi, S.A.; Shanahan, D.F.; Gaston, K.J.; Carrasco, R.L.; Fuller, R.A. Health and Wellbeing Benefits from Nature Experiences in Tropical Settings Depend on Strength of Connection to Nature. Int. J. Environ. Res. Public Health 2021, 18, 10149. https://doi.org/10.3390/ ijerph181910149

Academic Editor: Paul B. Tchounwou

Received: 31 August 2021

Accepted: 24 September 2021

Published: 27 September 2021

Publisher's Note: MDPI stays neutral with regard to jurisdictional claims in published maps and institutional affiliations.

Copyright: (C) 2021 by the authors Licensee MDPI, Basel, Switzerland. This article is an open access article distributed under the terms and conditions of the Creative Commons Attribution (CC BY) license (https:// creativecommons.org/licenses/by/ $4.0 /)$
Abstract: A growing number of policies and programmes in cities aim to increase the time people spend in nature for the health and wellbeing benefits delivered by such interactions. Yet, there is little research investigating the extent to which, and for whom, nature experiences deliver such benefits outside Europe, North America, and Australia. Here, we assessed the relationships between nature dose (frequency, duration, and intensity) and three mental wellbeing (depression, stress, and anxiety) and two physical health (high blood pressure, diabetes) outcomes in Singapore, an intensely urbanised tropical city. Our analyses accounted for individual factors, including socio-economic status, nature connection (nature relatedness), and whether people with poor health are prevented by their condition from visiting green spaces. Our results show that the association between nature dose (specifically duration) and mental wellbeing is moderated by a nature connection. Specifically, people with a stronger nature connection were less likely to be depressed, stressed, and anxious, regardless of the duration of their nature dose. For those with a weaker connection to nature, spending longer in nature was associated with being more depressed, stressed, and anxious. We did not find a relationship between nature dose and high blood pressure or diabetes. Our results highlight that the relationship between nature dose and wellbeing might vary substantially among cities.

Keywords: urbanisation; public health; health and wellbeing; nature exposure; nature experiences; nature dose

\section{Introduction}

Urbanisation has emerged as one of the most important global human health challenges of the 21st century [1,2]. While urban residents are on average wealthier and receive better nutrition and healthcare than rural dwellers [3], urban living has also been associated with increased risk of chronic disorders, a more demanding and stressful social environment, and greater social disparity [4,5]. Cities are becoming epicentres for chronic, non-communicable physical and mental health conditions [6-8], and meta-analyses have shown that people in urban settings have a substantially increased risk for anxiety, mood, and brain disorders [7-9]. Other urban health risks include pandemic outbreaks (e.g., SARSCoV-2 virus [10]), exposure to noise, water and air pollution, contagious diseases related 
to higher population density (e.g., tuberculosis), and risks associated with homelessness, violence, and inequality [11].

Exposure to nature has been proposed as a tool for providing health and wellbeing benefits in urban environments [12]. For example, health practitioners are increasingly prescribing nature-based experiences for patients living with specific health conditions $[13,14]$, while non-government organisations (NGOs) have lobbied for $1 \%$ of all health expenditure to be invested in nature-based solutions [15]. Indeed, there is a growing body of epidemiological evidence indicating that urban green spaces play a crucial role in addressing public health challenges [16-18]. While the quantity and quality of evidence varies across health outcomes, greater exposure to, or contact with, natural environments such as parks and forests has generally been associated with improved physical health (e.g., reduced blood pressure [19,20]; fewer allergies [21]), better self-reported general health [22,23], higher subjective wellbeing (e.g., reduced stress [24]; improved self-esteem and mood [25]; improved restoration [26,27]) and lower probability of mortality among adults [22,28]. In fact, the "dose" of nature exposure (e.g., frequency and duration of green space visits) is positively correlated with some of the benefits gained [29], and it has been estimated that up to $27 \%$ of depression cases could be prevented by spending five or more hours per week in a garden [30]. These findings highlight the possibility that exposure to nature makes a measurable contribution to health, and that urban green spaces may constitute a powerful public health intervention.

However, an urban environment comprises not only natural green spaces but also built (e.g., pedestrian sidewalks, buildings) and social (e.g., interactions between urban residents) components [31] that may have complex impacts on health and wellbeing outcomes. For example, some studies have reported that greater population densities are associated with better health and wellbeing outcomes, as densely populated urban neighbourhoods have infrastructure that encourages active modes of transport, such as walking [32], which are protective against cardiometabolic disease risk [33-35]. Cross-sectional studies from North America have shown that densely populated areas are associated with lower prevalence of obesity and type-2 diabetes [36,37]. Yet, urban living also brings its own risk factors for mental health. People living in urban areas have higher rates of psychiatric morbidity [38] and are at substantially increased risk of anxiety and mood disorders [8]. The incidence of schizophrenia, a major brain disorder, doubles in individuals born and raised in cities, with evidence of a dose-response relationship that probably reflects causation [6,7]. Yet, current population-level knowledge on relationships between every day nature exposure and health outcomes is predominantly shaped by research on and from cities in North America, Europe, and Australia. This is despite the fact that cities vary globally in many ways such as the amount and spatial configuration of urban green spaces [39], governmental policies and planning [40], local and regional climates within which cities are situated [41], socio-economic conditions and demography [42], and human behaviour, perceptions, and values $[43,44]$. For example, there is considerable variability in peoples' connection to nature, i.e., the extent to which people are attracted to nature. This human-nature relationship is multidimensional, consisting of affect (feelings towards nature), cognition (knowledge and beliefs about nature), and behaviour (actions and experiences in nature) [45]. These differences therefore raise the question of whether the health benefits from exposure to nature might vary, and to what extent, for cities beyond North America, Europe, and Australia.

To address this question, we conducted a cross-sectional study of urban dwellers in Singapore, a densely occupied tropical city. We measured three aspects of nature dose (i.e., direct exposure to nature [46]) - the frequency and duration of a person's everyday nature exposure, and the intensity (i.e., the quality and quantity) of that exposure. We focused on three mental wellbeing (depression, anxiety, and stress) and two physical health (high blood pressure and diabetes) outcomes, as these are pertinent to living in cities and there is evidence that nature exposure confers some protection against poor outcomes [47]. Most studies have assumed that nature exposure results in positive health outcomes, but have 
been unable to exclude potential reverse causality in which people with poor health may be less likely to spend time in nature because of their health condition. Our study attempts to account, in part, for this possibility by asking people whether poor health prevents them from visiting urban green spaces; we then include this as a variable in our statistical analyses.

\section{Materials and Methods}

Study Site-We chose Singapore as a study site as it is a highly urbanised and densely populated tropical city. The city-state has a total land area of $724 \mathrm{~km}^{2}$ [48], with a population of 5.7 million residents [49]. While the city-state has an average population density of 7804 residents per square kilometre, the urban population density (i.e., ratio of the total urban population of the city and its urban area) can reach 18,600 residents per square kilometre [50]. This is much higher than average urban population densities in European (e.g., London: 6300 residents $/ \mathrm{km}^{2}$, Berlin: 5600 residents $/ \mathrm{km}^{2}$ ), American (e.g., New York: 3300 residents $/ \mathrm{km}^{2}$, Los Angeles: 3300 residents $/ \mathrm{km}^{2}$ ), and Chinese (e.g., Beijing: 7800 residents $/ \mathrm{km}^{2}$, Shanghai: 7600 residents $/ \mathrm{km}^{2}$ ) cities [50].

Survey-We delivered an online survey to Singapore residents within a one-month window in January 2019 through a market research company to a stratified subset of adults (18 years and above) voluntarily enrolled in their survey database. This survey was conducted in accordance with the University of Queensland Institutional Human Research Ethics Approval (project number 2018001775) and the Institutional Review Board at the National University of Singapore (project reference S-18-344). Informed consent was obtained from all respondents through a tick-box. Respondents were stratified by several nested criteria to ensure that the final sample was representative of the Singapore population in terms of standard demographic characteristics, with an even spatial distribution across the city. The stratification criteria were-(i) gender ( $50 \%$ males, $50 \%$ females); (ii) age ( $50 \%$ aged 18 to less than 45 years old, $50 \%$ aged 45 to 75 years old); (iii) personal income (reflecting the four quartiles from the national census); and (iv) greenery surrounding current residence (reflecting the four quartiles of tree cover across the city).

Exposure to nature-We measured three aspects of exposure to nature, namely the duration and frequency of nature experiences, and nature intensity through a mixture of self-reported and remote sensing analysis.

Respondents first reported on the duration of "outdoor green space" visit(s). Green space was introduced as: "For example, this includes beaches, parks and nature reserves, rooftop gardens, golf courses and gardens." The estimated average duration of one green space visit was based on the self-reported number of hours spent during each visit in the previous week. We chose this timeframe as it provided a short and recent reference period to improve recall accuracy [51]. We summed the total number of hours spent across all visits in the previous week and capped it at $34 \mathrm{~h}$, as $98 \%$ of the respondents reported spending a total of $\leq 34 \mathrm{~h}$ on green space visits. We then averaged the total duration by the number of green space visits in the previous week.

Respondents also reported the estimated frequency of regular green space visits in the past year. This was capped at 300 visits to avoid exaggerated positive skews in the frequency estimates, as $98 \%$ of respondents reported $\leq 300$ visits in the past year. Compared to the duration measurement, we chose a different timeframe to allow us to account for people who visited green spaces infrequently, such as those who visit green spaces less than once a week and would not have been captured by the above duration measure, as well as to minimise correlation with the duration measure.

We also generated two measures of nature intensity, and this was made possible as respondents had provided the name of green spaces visited in the previous week. Nature intensity refers to the vegetation complexity within visited green spaces. It was chosen as it is an indicator of ecological complexity, and higher ecological complexity has been correlated with higher levels of biodiversity [52-54] and could lead to improved health outcomes [55]. We first geolocated the green spaces by aligning the provided names with 
the established spatial boundaries as per the Singapore Masterplan 2019 [56] in ArcGIS. We then overlaid a classified map of terrestrial ecosystems in Singapore, comprising four landcover categories (i.e., vegetation with limited human management [with Tree Canopy]; vegetation with structure dominated by human management [with Tree Canopy]; freshwater swamp forest; mangrove forest) with a $5 \times 5$ m resolution [57]. Following this, we generated two measures of nature intensity to represent the possible multiple pathways linking nature and health outcomes [29] - (i) the average area of tree cover within the largest vegetated green space visited by each respondent (quantity); and (ii) the proportion of the average area of tree cover that is managed by humans (quality). The quantity was derived using the spatial boundaries delineating each park, while the quality of green space was calculated by dividing the area of "vegetation with structure dominated by human management (with tree canopy)" by the quantity of green space as computed above. We included the second variable to differentiate between tree cover that is natural and unmanaged from tree cover that is managed, as areas in Singapore with high natural greenery are likely to be more biodiverse than those that are highly managed [58]. Smaller values of quality of green spaces indicated less complex vegetation. Measures involving nature intensity were limited to larger urban green spaces such as parks and nature reserves (rather than community and rooftop gardens) as these could be geo-located through the provided names and had established spatial boundaries as per the Singapore Masterplan 2019 [56].

Heath outcomes-Respondents provided information on three dimensions of mental wellbeing (i.e., depression, anxiety, and stress) and two physical health (high blood pressure and diabetes) outcomes. For mental wellbeing, we generated measures of depression, anxiety, and stress (experienced in the past week) using the Depression, Anxiety and Stress Scale (DASS21 [59]). Respondents rated a set of 21 statements with four responses ranging from " $0=$ Not applicable to me", " 1 = Applicable some of the time", " 2 = Applicable for a good part of time", and " 3 = Applicable for most of the time". Within the set of 21 statements, 3 sets of 7 statements measured depression, anxiety, and stress, respectively. With regard to physical health, respondents reported whether they were currently receiving treatment for high blood pressure or diabetes. This was coded as a binary variable $(0=$ not receiving medical treatment; 1 = receiving medical treatment).

Covariates-We collected socio-demographic covariates including age, personal income, gender, ethnicity, highest formal education, and number of workdays per week, as these have been tied to health outcomes and experiences of nature in previous studies $[28,29,60-63]$. We also measured an individual's connection to nature using the nature relatedness scale [64], where respondents were invited to rate a set of 21 statements using a five-point Likert scale ranging from 1 (disagree strongly) to 5 (agree strongly). An aggregation of the responses (as per [64]) provided a measure of an individual's relationship with nature, with a higher score indicating a stronger connection with nature. Although the three sub-scales can be combined to form a unidimensional scale, we retained the three separate established sub-scales, and used two in our study-(i) NR-Self (affective), which assesses how strongly one identifies with nature (e.g., my relationship to nature is an important part of who I am); and (ii) NR-Experience (experiential), which indicates one's physical familiarity, and attraction, with nature (e.g., I enjoy being outdoors, even in unpleasant weather [64]), as these sub-scales are likely to differentiate between groups of individuals who engage with nature to a greater or lesser extent. We additionally controlled for whether poor health prevented respondents from spending time in outdoor green spaces. This binary covariate comprised two groups of respondents-those who had indicated (i) "often" and "most of the time"; or (ii) "never" and "sometimes", when asked about the extent to which "poor health" prevents them from spending time in an outdoor green space.

Statistical Analyses-We conducted all analyses in R version 3.6.2 [65]. We constructed a total of five global models to examine the correlation between each health response and potential predictors. We used cumulative link mixed models (CLMM) for depression, anxiety, and stress (ordinal package [66]) because the response variable (i.e., rating of each 
statement) is an ordered factor variable, and generalised linear models (binomial) for both high blood pressure and diabetes, because the response variable is a binary variable.

The predictor variables specified for the models are summarised in Table 1. All continuous predictors were standardised. We also included four interaction terms (duration and frequency of green space visit with each nature relatedness subscale), as the association between nature dose and health may be dependent on one's connection to nature (nature relatedness). A Hessian condition number was used to assess goodness-of-fit for CLMMs [67], while residuals of fitted models were assessed for generalised linear models. Prior to all analyses, we assessed multicollinearity in each global model using the vif function from the car package [68], and found no such issues (VIF <3).

Table 1. Description of the predictor variables specified in each of the five global models where response variables are depression, anxiety, stress, high blood pressure, and diabetes.

\begin{tabular}{|c|c|}
\hline Variable & Description \\
\hline Age (linear) & Respondents provided their age in years. \\
\hline Personal income (linear) & $\begin{array}{l}\text { Respondents selected from } 16 \text { income brackets *. For analysis purposes, the mid- } \\
\text { point of each income bracket was used and treated as a continuous variable. }\end{array}$ \\
\hline Gender (categorical) & Female or male. \\
\hline Ethnic group (categorical) & $\begin{array}{l}\text { Respondents selected from: Chinese, Malay, Indian, Eurasian, Others. For analysis } \\
\text { purposes, these were later aggregated to two categories: ethnic majority (Chinese) } \\
\text { and minorities (Malay, Indian, Eurasian, Others). }\end{array}$ \\
\hline Education (categorical) & $\begin{array}{l}\text { Respondents indicated their highest formal education by selecting from } 10 \text { catego- } \\
\text { ries *. For analysis purposes, these were later aggregated into two categories: No } \\
\text { bachelor's degree and bachelor's degree and higher. }\end{array}$ \\
\hline Number of workdays per week (linear) & The number of days the respondent works in an average week. \\
\hline Physical activity (linear) & $\begin{array}{l}\text { Number of days in the last week where the respondent engaged in vigorous physi- } \\
\text { cal activity. }\end{array}$ \\
\hline Body mass index (linear) & $\begin{array}{l}\text { Respondent's body mass index (BMI), calculated as: weight in kilograms divided } \\
\text { by height in metres squared. }\end{array}$ \\
\hline Social cohesion (linear) & $\begin{array}{l}\text { A measure of a respondent's perceptions of social cohesion as derived from three } \\
\text { questions *, with higher scores representing stronger social cohesion. }\end{array}$ \\
\hline $\begin{array}{l}\text { Ability (or inability) to access green space } \\
\text { because of poor health (binary) }\end{array}$ & $\begin{array}{l}\text { Respondents indicated the extent to which poor health prevents them from spend- } \\
\text { ing time in outdoor green spaces. Respondents selected from: never; sometimes; of- } \\
\text { ten; most of the time. For analysis purposes, these were later aggregated into two } \\
\text { categories: unable to access green space because of poor health (responses of "of- } \\
\text { ten" and "most of the time") and able to access green space because of poor health } \\
\text { (responses of "never" and "sometimes"). }\end{array}$ \\
\hline NR-Self (linear) & $\begin{array}{l}\text { A measure of a respondent's ecological identity as derived from the nature related- } \\
\text { ness affective sub-scale *, with higher scores representing stronger NR-Self. }\end{array}$ \\
\hline NR-Experience (linear) & $\begin{array}{l}\text { A measure of a respondent's familiarity with nature as derived from the nature re- } \\
\text { latedness experiential sub-scale *, with higher scores representing stronger NR-Ex- } \\
\text { perience. }\end{array}$ \\
\hline Frequency of green space visits (linear) & $\begin{array}{l}\text { Self-reported number of visits to public outdoor } \\
\text { green spaces in the past year. }\end{array}$ \\
\hline Duration of green space visits (linear) & $\begin{array}{l}\text { Self-reported average number of hour(s) spent during each visit to public outdoor } \\
\text { green spaces in the week prior to completing the survey. }\end{array}$ \\
\hline Nature intensity (linear) & $\begin{array}{l}\text { Area of tree canopy within the most vegetated outdoor green space visited by each } \\
\text { respondent, and the proportion of that which is human-managed. }\end{array}$ \\
\hline
\end{tabular}

* See Oh et al. [63] for the full list of response options or statements. 
We further conducted two types of sensitivity analyses. First, we analysed the depression, anxiety, and stress data using generalised negative binomial linear models (MASS package [69]) instead of CLMMs, as it was possible that a different treatment of the response variable (from ordinal to continuous) might result in a different set of significant predictors between model types. For this sensitivity analysis, we therefore aggregated the responses to form a continuous score that provided a measure of an individual's extent of depression, anxiety, and stress, respectively, with a higher score indicating more severe depression, anxiety, and stress. The significant parameters were very similar to the CLMM analyses and are reported in the Supplementary Materials S1 (Tables S1-S4). For the second sensitivity analysis, we analysed only the depression and high blood pressure data by emulating as closely as possible the statistical methods used by Shanahan et al. [29], as they measured these health outcomes and predictor variables using very similar questions. Specifically, we converted the aggregated depression score into a binary measure where 0 indicated no depression (i.e., aggregated scores of 0-4; as per Shanahan et al. [29]) and 1 indicated mild or worse depression (i.e., aggregated scores of $\geq 5$ ). We did so for two reasons: it was possible that (i) a different treatment of the depression response (from ordinal to binary); and (ii) the specification of four additional interaction terms between nature-relatedness and duration and frequency of green space used could result in a different set of significant predictors. We report these results in the Supplementary Materials S2 (Table S5) given that the significant predictors and direction of relationships between significant predictors were generally consistent with the CLMM analyses.

Lastly, we analysed whether individuals whose poor health prevented them from accessing outdoor green spaces were associated with any specific socio-economic factors by constructing a generalised linear (binomial) model. The binary response variable was whether the respondent indicated that poor health prevented them from spending time in outdoor green spaces, and the predictor variables were age, income, gender, education, and ethnicity.

\section{Results}

We received a total of 1499 responses to the urban lifestyle survey in Singapore. The respondent pool closely reflected the intended stratification criteria. The ethnic composition of the respondents approximated that of the national population (i.e., $70 \%$ Chinese, $15 \%$ Malay, 7\% Indian, and 8\% Others [70]).

\subsection{Mental Wellbeing Outcomes}

Overall, we found that nature dose (i.e., frequency, duration, and intensity) was not categorically associated with positive health and wellbeing outcomes. Instead, the strength of nature connection, in particular NR-Self, moderated the relationship between the duration of green space visits and all three mental wellbeing outcomes (Table 2). People with higher NR-Self were less likely to show symptoms of depression, stress, and anxiety, regardless of the duration of their exposure to nature. Conversely, for those with lower NRSelf, longer durations of nature exposure were correlated with higher levels of depression, stress, and anxiety (Figure 1). We also found that people whose health did not impede their use of green spaces were less likely to show symptoms of depression, stress, and anxiety (Table 2). Being older and non-Chinese was significantly associated with lower levels of depression, stress, and anxiety (Table 2). These results were comparable with the results from the two sensitivity analyses (reported in the Supplementary Materials). 
Table 2. The relationship between mental wellbeing outcomes (i.e., depression, stress, and anxiety), socio-demographic covariates, and nature exposure predictor variables. Hessian condition number (Cond. H) and estimated parameter coefficients are presented from the CLMMs, with standard error in brackets; negative coefficients indicate that prevalence of depression, stress, and anxiety are lower with higher values of predictor variables. Table cells shaded in grey (with bold numbers) represent significant predictor variables ( $p$-value $\leq 0.05)$. An asterisk represents an interaction between two predictor variables. The estimated parameter coefficients and confidence intervals for categorical factors are presented relative to a comparative base factor level: Education: no bachelor's degree; gender: male; ethnicity: majority Chinese; inability to access green space because of poor health).

\begin{tabular}{|c|c|c|c|}
\hline Predictor Variables & Depression & Stress & Anxiety \\
\hline & Cond. $\mathrm{H}=2.6 \times 10^{3}$ & Cond. $\mathrm{H}=2.3 \times 10^{3}$ & Cond. $\mathrm{H}=8.6 \times 10^{1}$ \\
\hline Age & $-0.45(0.05)$ & $-0.28(0.04)$ & $-0.30(0.03)$ \\
\hline Personal Income & $-0.08(0.06)$ & $-0.09(0.05)$ & $-0.04(0.04)$ \\
\hline Education (bachelor's degree) & $-0.06(0.10)$ & $0.03(0.08)$ & $-0.07(0.07)$ \\
\hline Gender (female) & $-0.08(0.10)$ & $0.11(0.08)$ & $0.04(0.06)$ \\
\hline Ethnicity (minorities) & $-0.24(0.11)$ & $-0.20(0.09)$ & $-0.15(0.08)$ \\
\hline Number of work days & $-0.01(0.05)$ & $0.04(0.04)$ & $-0.01(0.03)$ \\
\hline Body Mass Index & $-0.01(0.05)$ & $-0.03(0.04)$ & $0.01(0.03)$ \\
\hline Physical activity & $0.03(0.05)$ & $0.08(0.04)$ & $0.07(0.03)$ \\
\hline Duration of green space visit & $1.17(0.44)$ & $0.90(0.35)$ & $0.06(0.04)$ \\
\hline Frequency of green space visits & $-0.32(0.43)$ & $-0.15(0.34)$ & $-0.10(0.04)$ \\
\hline Average tree cover & $-0.02(0.05)$ & $-0.01(0.04)$ & $-0.01(0.03)$ \\
\hline Proportion of tree cover that is managed & $0.03(0.11)$ & $0.09(0.09)$ & $-0.02(0.08)$ \\
\hline NR_Self & $-0.21(0.10)$ & $-0.07(0.08)$ & $-0.08(0.04)$ \\
\hline NR_Experience & $-0.08(0.06)$ & $-0.07(0.05)$ & $-0.06(0.04)$ \\
\hline Social Cohesion & $-0.18(0.05)$ & $-0.07(0.04)$ & $0.01(0.03)$ \\
\hline Ability to access green space & $-0.69(0.13)$ & $-0.61(0.11)$ & $-0.56(0.09)$ \\
\hline Duration of green space visits * NR_Self & $-0.30(0.12)$ & $-0.23(0.10)$ & $-0.10(0.04)$ \\
\hline Frequency of green space visits * NR_Self & $0.06(0.12)$ & $0.01(0.10)$ & $0.02(0.05)$ \\
\hline Duration of green space visits * NR_Experience & $0.08(0.07)$ & $0.06(0.06)$ & $0.08(0.05)$ \\
\hline Frequency of green space visits * NR_Experience & $0.04(0.06)$ & $0.06(0.05)$ & $-0.01(0.04)$ \\
\hline
\end{tabular}

\section{A) Depression}

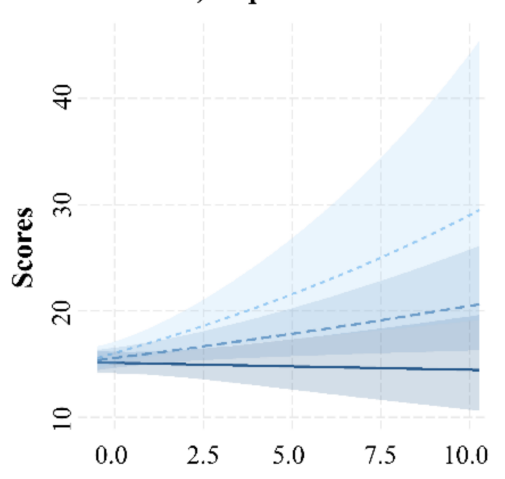

B) Stress

马

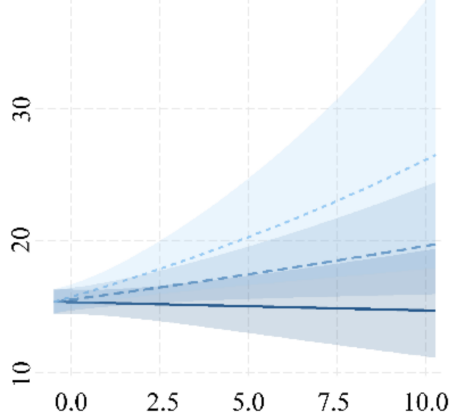

Duration of green space visit (hours)
C) Anxiety

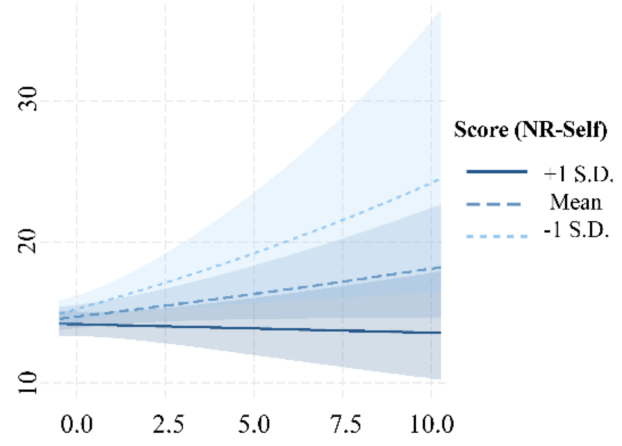

Figure 1. Interaction plots from the mixed-effects model showing the relationship between duration of nature interaction with each mental wellbeing score-(A) depression; (B) stress; and (C) anxiety. Fitted lines represent the mean, +1 standard deviation (S.D.), and -1 standard deviation scores for ecological identity (i.e., nature relatedness-self). Shaded area represents confidence intervals. 
There were also slight variations in the factors that were significantly associated with each mental wellbeing outcome. Lower levels of depression were significantly associated with stronger feelings of social cohesion (Table 2; Supplementary Materials S1. Lower levels of stress were significantly associated with higher personal income and less exercise (Table 2), while lower levels of anxiety were significantly associated with more frequent green space visits and less exercise (Table 2).

\subsection{Physical Health Outcomes}

With regard to physical health outcomes, $10.7 \%(n=160)$ and $4.3 \%(n=64)$ of all respondents $(n=1499)$ were receiving medical treatment for high blood pressure and diabetes, respectively. Both age and BMI were significantly and positively associated with the likelihood of receiving medical treatment for high blood pressure and diabetes (Table 3). There was no significant association between any measures of exposure to nature (and the specified interactions with connection to nature) and the likelihood of receiving treatment for high blood pressure or diabetes (Table 3). There were, however, slight variations in the factors that were significantly associated with each physical wellbeing outcome. Individuals whose health did not impede their use of green spaces were less likely to be receiving medical treatment for high blood pressure. Less exercise but stronger feelings of social cohesion was associated with a higher likelihood of receiving treatment for diabetes (Table 3).

Table 3. The relationship between physical health outcomes (high blood pressure and diabetes), socio-demographic covariates, and nature exposure predictor variables. The Nagelkerke/Crag and Uhler's pseudo $\mathrm{R}^{2}$ and estimated parameter coefficients are presented from the negative binomial GLMs, with standard error in brackets. Table cells shaded in grey (with bold numbers) represent significant predictor variables ( $p$-value $\leq 0.05$ ). An asterisk represents an interaction between two predictor variables.

\begin{tabular}{|c|c|c|}
\hline Predictor Variables & High Blood Pressure & Diabetes \\
\hline & Pseudo $R^{2}=0.35$ & Pseudo $\mathrm{R}^{2}=0.21$ \\
\hline Age & $1.35(0.13)$ & $0.91(0.16)$ \\
\hline Personal Income & $0.17(0.12)$ & $-0.06(0.18)$ \\
\hline Education (bachelor's degree) & $-0.35(0.22)$ & $-0.59(0.33)$ \\
\hline Gender (female) & $-0.19(0.21)$ & $-0.54(0.30)$ \\
\hline Ethnicity (minorities) & $-0.53(0.28)$ & $-0.24(0.38)$ \\
\hline Number of work days & $0.01(0.11)$ & $-0.11(0.14)$ \\
\hline Body Mass Index & $0.77(0.10)$ & $0.49(0.13)$ \\
\hline Physical activity & $0.10(0.10)$ & $-0.37(0.19)$ \\
\hline Duration of green space visit & $-0.03(0.10)$ & $-0.07(0.18)$ \\
\hline Frequency of green space visits & $0.02(0.11)$ & $-0.22(0.22)$ \\
\hline Average tree cover & $0.05(0.10)$ & $0.15(0.13)$ \\
\hline Proportion of tree cover that is managed & $-0.27(0.25)$ & $-0.17(0.35)$ \\
\hline NR_Self & $-0.21(0.13)$ & $-0.12(0.18)$ \\
\hline NR_Experience & $0.09(0.13)$ & $0.02(0.19)$ \\
\hline Social Cohesion & $0.13(0.11)$ & $0.36(0.17)$ \\
\hline Ability to access green space & $-0.80(0.26)$ & $-0.32(0.37)$ \\
\hline Duration of green space visits * NR_Self & $0.06(0.15)$ & $0.14(0.21)$ \\
\hline Frequency of green space visits * NR_Self & $-0.06(0.13)$ & $0.04(0.24)$ \\
\hline Duration of green space visits * NR_Experience & $-0.01(0.16)$ & $-0.16(0.25)$ \\
\hline Frequency of green space visits * NR_Experience & $-0.04(0.13)$ & $0.05(0.23)$ \\
\hline
\end{tabular}


Overall, $14 \%$ of respondents $(n=212)$ were unable to access outdoor green spaces because of poor health; they were generally older people (Table 4).

Table 4. The relationship between whether a person was able or unable to access outdoor green spaces because of poor health, and five socio-demographic predictor variables. The Nagelkerke/Crag and Uhler's pseudo $\mathrm{R}^{2}$ and estimated parameter coefficients are presented from the GLM, with standard error in brackets. Table cells shaded in grey (with bold numbers) represent significant predictor variables ( $p$-value $\leq 0.05)$. The estimated parameter coefficients and confidence intervals for categorical factors are presented relative to a comparative base factor level: Education: no bachelor's degree; gender: male; ethnicity: majority Chinese).

\begin{tabular}{lc}
\hline \multicolumn{1}{c}{ Predictor Variables } & Estimated Coefficient (Standard Error) \\
\hline Age & Pseudo $\mathbf{R}^{2}=0.01$ \\
\hline Personal Income & $\mathbf{0 . 2 0}(\mathbf{0 . 0 8 )}$ \\
\hline Education (Bachelor's degree) & $0.01(0.09)$ \\
\hline Gender (Female) & $-0.04(0.17)$ \\
\hline Ethnicity (Minorities) & $-0.04(0.15)$ \\
\hline
\end{tabular}

\section{Discussion}

In this context of a densely populated, highly urbanised, multicultural, and tropical city, we found no direct relationship between nature dose and health and wellbeing outcomes. Instead, we found that nature connection (specifically, NR-Self) moderated the relationship between duration of nature exposure and mental wellbeing outcomes wherein individuals with a stronger connection to nature were less likely to exhibit symptoms of depression, stress, and anxiety, regardless of how long they spent in nature, while individuals with a weaker connection to nature were more likely to show more symptoms, with an increasing duration spent in nature. The lack of a direct relationship between nature dose measures and beneficial mental wellbeing outcomes was surprising, as these relationships were found in a Brisbane study [63]. Moreover, direct, multi-sensory exposure to nature has been shown to promote positive mental wellbeing outcomes via pathways that involve physical activity and social support. Indeed, visual greenery in vegetation, the scent of flowers and tree oils, and the songs of birds have all been shown to improve mental wellbeing $[47,71,72]$ through various human senses [73]. Similarly, living near green spaces promotes a higher frequency and intensity of exercise [74,75], which in turn improves mental wellbeing [76], and by serving as places where local communities interact socially, strengthening social support that ameliorates loneliness and improves wellbeing $[77,78]$. However, when summed across different types of nature exposure ranging from direct (time spent in parks and on gardening), indirect (view of nature through windows) and incidental (time in nature as part of work), an average Singapore resident only had half the amount of exposure ( $25.8 \mathrm{~h}$ per week) compared to those living in Australia ( $52.3 \mathrm{~h}$ per week [63]) and the United Kingdom (57.3 h per week [30]).

Our results show that the relationship between nature exposure and wellbeing might vary depending on city context, and this is an important finding with policy and programming implications. The finding of an interaction between nature dose and connection to nature on mental wellbeing outcomes contrasts with several prior studies, where increased durations were found to be directly associated with a decrease in depression [29], and where nature-based activities were associated with lower anxiety levels compared to indoor activities [79]. Conversely, our finding that people with a higher connection to nature had fewer mental wellbeing symptoms aligns with research showing that people with stronger nature relatedness (and other similar psychological constructs such as nature connectivity, nature connectedness) have lower levels of anxiety [80] and improved subjective wellbeing [81-83]. Viewed holistically, this particular result indicates that strengthening how 
strongly people identify with the natural environment (ecological identity; NR-Self) could be important for promoting mental wellbeing benefits. Indeed, nature relatedness, or the cultural and social differences in how people perceive and construe their connection with the natural world [84], could motivate interactions with nature and enhance wellbeing [85]. In this regard, Singapore differs from many other places where such studies have been conducted. The city-state is situated in tropical south-east Asia (non-European setting), and where citizens embody a strong national identity and culture where green is integrated into daily living [86] and widely considered key to quality of life [87]. Relatedly, climate conditions unique to Singapore's equatorial position such as higher average temperatures and humidity and regular monsoonal rainfall could also be physically uncomfortable for people to spend long durations in outdoor green spaces. These reasons could be why we found that NR-Self (ecological identity) but not NR-Experience (familiarity with nature) was associated with positive wellbeing outcomes, while other studies found that it was NR-Experience but not NR-Self that was associated with lower levels of anxiety [80,88]. It would be interesting to conduct a longitudinal study in Singapore to investigate how peoples' construction of nature and connection with different types of nature change over time.

Our finding that people with a weaker connection to nature tended to have more symptoms of stress, depression, and anxiety with increasing duration spent in nature was also unexpected. Perhaps this subgroup comprised people who are generally disinterested or uncomfortable with spending time in nature, and prefer urban environments, modern comforts, or indoor recreational activities [89]. Alternatively, duration spent in nature could be a proxy for other activities such as physical exercise. As such, the positive correlation between higher levels of stress, depression, and anxiety with longer durations of time spent in nature could indicate a coping strategy (of increased engagement in physical exercise) that some individuals take to manage their stress levels [90]. Nonetheless, further investigation is required to understand how weakly connected individuals interact with nature, their perceptions of such interactions, and the activities that they engage in that benefit their health and wellbeing.

One strength of our study was our attempt to account (statistically) for a potential reverse pathway by having a covariate representing whether poor health impeded certain individuals from spending time in nature. We do so because individuals clinically diagnosed with anxiety or depression tend to have reduced overall physical activity levels when compared to healthy controls [90,91]. We found that, when compared to people whose poor health impeded their use of green spaces, the group reporting that poor health did not impede their use of green space had lower levels of depression, stress, and anxiety, and were less likely to be treated for high blood pressure. However, given that we did not find a significant relationship between nature dose and wellbeing, but a relationship moderated by one's connection to nature, it is possible that the widely reported positive associations between nature exposure and health may be caused in part by healthier and more nature-connected people simply using green spaces more. Future studies could take longitudinal approaches that track people's nature exposure and health outcomes at regular temporal intervals in a methodologically more rigorous manner than the cross-sectional study reported here.

We found no significant relationship between nature intensity (i.e., the quality of the natural environment) and mental wellbeing, despite some studies suggesting that more biodiverse environments are associated with positive health outcomes [30,92-94]. Comparing among studies that used tree cover as a measure of nature intensity, only one study echoed our findings [95], while others found that tree cover was associated with other wellbeing outcomes such as greater reflection, continuity with the past and attachment [26], and personal wellbeing [96]. Given that the availability of nature in Singapore is arguably saturated, since green cover is equitably distributed [97], predominantly publicly accessible, and present all year round due to its tropical (non-temperate) geolocation, it could be that other indices of nature quality are required to better distinguish between the ecological 
complexity in tropical natural ecosystems. Perhaps a more direct measure such as visual complexity of elements in the landscape, including their shapes and how these are arranged in space [98], might prove to be more relevant in the context of mental wellbeing [99]. Alternatively, it could be cultural or between-individual differences in how a person connects to, values, and perceives nature [100], measurements that were not captured by "tree cover", that best deliver wellbeing benefits. For example, the bulk of nature-health studies have been conducted in European and North American settings, and those cultures may simply differ in the way they connect to, and value, nature when compared to a tropical Asian setting. As such, fundamental social, cultural, and geophysical differences between cities could impact the quantity and quality of nature dose experienced by people. Nonetheless, our measures of nature dose are self-reported, and likely less comprehensive than those obtained via geo-tracking individuals during an actual green space visit [101] or across several days [102]. We also focused our measures of exposure to nature on green space visits. While this is the predominant type of urban green space in Singapore, time spent on gardening can also be an important means of meaningful contact with nature for many, delivering substantial human health benefits [103].

We found no significant relationship between exposure to nature and both physical health outcomes (high blood pressure and diabetes). This was unexpected for diabetes, a health outcome that is highly dependent on diet and lifestyle [104,105], since having active lifestyles and optimal weights are protective against type-2 diabetes [106]. Given that living near green spaces promotes a higher frequency and intensity of exercise [74,107,108], with some groups (e.g., women) also having a lower BMI [109], we expected some measures of nature dose to be associated with a lower risk of diabetes. Our findings therefore differed from those who found that greater exposure to nature correlated with a lower risk of type-2 diabetes [110]. Of interest was that social cohesion was positively associated with diabetes, suggesting that there might be socio-cultural influences that affect food consumption patterns in ways detrimental to personal health, such as the consumption of staples high in carbohydrates [111]. We did find, however, that age and body mass index were positively associated with an increase in likelihood of receiving treatment for high blood pressure and diabetes, which aligns with other adult- [18,112,113] and childpopulation health studies [114,115], even after controlling for socio-economic factors. Our findings on high blood pressure as a health outcome adds another datapoint to the current state of mixed findings wherein a reduction in blood pressure (in response to exposure to nature) was reported in some studies $[76,116,117]$ but not others $[77,118]$. Such mixed findings could be an artefact of our choice of response variable, where the occurrence of whether an individual was receiving treatment for diabetes or high blood pressure could be under-reported because of a fear or reluctance to report the truth, or that there are undiagnosed cases of diabetes and high blood pressure in our sample [119,120]. Future studies should consider conducting long-term studies on clinically diagnosed individuals, or stratify the sample so that it approximates the national population of people diagnosed with diabetes/high blood pressure, to better follow the relationships between changes in nature exposure and impact on physical health status.

\section{Conclusions}

We assessed the relationships between direct exposure to nature (frequency, duration, and intensity) and three mental wellbeing (depression, stress and anxiety) and two physical health (high blood pressure, diabetes) outcomes. In this context of a densely populated tropical city, we found that the relationship between duration of green space visits and mental wellbeing outcomes is moderated by nature connection. People with a stronger connection to nature had lower levels of depression, stress, and anxiety (regardless of duration of nature dose), while those with a weaker connection to nature but who spent longer durations in nature were more likely to be depressed, stressed, and anxious. We did not find a relationship between nature dose and incidence of high blood pressure and diabetes, nor a relationship between quantity and quality of green space with health 
and wellbeing outcomes. Viewed holistically, our results highlight a complex relationship between nature dose and health and wellbeing benefits that could vary from city to city driven by local social, cultural, and geophysical differences. Thus, locally relevant evidence, strategies, and policies are necessary to connect people to nature in ways that benefit their health and wellbeing.

Supplementary Materials: The following are available online at https://www.mdpi.com/article/10 .3390 /ijerph181910149/s1, Table S1: The average score and standard error for each of the three mental health outcome (depression, stress and anxiety) and two nature connection sub-scales (NR-Self, NR-Experience) as used in the GLM analyses, Table S2: The relationship between depression as a health outcome, socio-demographic covariates and nature exposure predictor variables, Table S3: The relationship between anxiety as a health outcome, socio-demographic covariates and nature exposure predictor variables, Table S4: The relationship between stress as a health outcome, socio-demographic covariates and nature exposure predictor variables, Table S5: The relationship between two health outcomes (the response variables) of depression and high blood pressure, socio-demographic covariates, and nature experience predictor variables.

Author Contributions: Conceptualization, R.R.Y.O., K.S.F., D.F.S., K.J.G., R.L.C. and R.A.F.; Data Curation, R.R.Y.O.; Formal analysis, R.R.Y.O.; Funding Acquisition, R.R.Y.O. and R.L.C.; Investigation, C.-C.C., L.T.P.N., C.L.Y.T. and R.A.F.; Methodology, R.R.Y.O., K.S.F., D.F.S., K.J.G., R.L.C. and R.A.F.; Project Administration, R.L.C.; Supervision, K.S.F. and R.A.F.; Writing-Original Draft, R.R.Y.O.; Writing-Review and Editing, R.R.Y.O., K.S.F., C.-C.C., L.T.P.N., C.L.Y.T., S.A.Q., D.F.S., K.J.G., R.L.C. and R.A.F. All authors have read and agreed to the published version of the manuscript.

Funding: This study was funded by the Ministry of National Development and the National Parks Board, Singapore [Grant number R-154-000-B05-490]. R.R.Y.O. acknowledges scholarship support from the Commonwealth Government of Australia.

Institutional Review Board Statement: This survey was conducted in accordance with the University of Queensland Institutional Human Research Ethics Approval (project number 2018001775) and the Institutional Review Board at the National University of Singapore (project reference S-18-344).

Informed Consent Statement: Informed consent was obtained from all subjects involved in the study.

Data Availability Statement: Upon acceptance of the manuscript, the data will be publicly archived and made available.

Acknowledgments: Special thanks to Leon Gaw for geospatial support.

Conflicts of Interest: The authors declare no conflict of interest.

\section{References}

1. Moore, M.; Gould, P.; Keary, B.S. Global Urbanization and Impact on Health. Int. J. Hyg. Environ. Health 2003, 206, 269-278. [CrossRef]

2. Gong, P.; Liang, S.; Carlton, E.J.; Jiang, Q.; Wu, J.; Wang, L.; Remais, J.V. Urbanisation and Health in China. Lancet 2012, 379, 843-852. [CrossRef]

3. World Health Organization; United Nations; Human Settlements Programme. Hidden Cities: Unmasking and Overcoming Health Inequities in Urban Settings; WHO Press: Geneva, Switzerland, 2010; p. 145.

4. Berry, H.L. "Crowded Suburbs" and "Killer Cities": A Brief Review of the Relationship between Urban Environments and Mental Health. NSW Public Health Bull. 2007, 18, 222. [CrossRef] [PubMed]

5. Dye, C. Health and Urban Living. Science 2008, 319, 766-769. [CrossRef] [PubMed]

6. Pedersen, C.B.; Mortensen, P.B. Evidence of a Dose-Response Relationship Between Urbanicity During Upbringing and Schizophrenia Risk. Arch. Gen. Psychiatry 2001, 58, 1039-1046. [CrossRef] [PubMed]

7. Krabbendam, L.; van Os, J. Schizophrenia and Urbanicity: A Major Environmental Influence-Conditional on Genetic Risk. Schizophr. Bull. 2005, 31, 795-799. [CrossRef]

8. Peen, J.; Schoevers, R.A.; Beekman, A.T.; Dekker, J. The Current Status of Urban-Rural Differences in Psychiatric Disorders. Acta Psychiatr. Scand. 2010, 121, 84-93. [CrossRef] [PubMed]

9. Gruebner, O.A.; Rapp, M.; Adli, M.; Kluge, U.; Galea, S.; Heinz, A. Cities and Mental Health. Dtsch Arztebl Int. 2017, 114, 121-127. [CrossRef]

10. Costa, D.G.; Peixoto, J.P.J. COVID-19 Pandemic: A Review of Smart Cities Initiatives to Face New Outbreaks. IET Smart Cities 2020, 2, 64-73. [CrossRef] 
11. Galea, S.; Vlahov, D. URBAN HEALTH: Evidence, Challenges, and Directions. Annu. Rev. Public Health 2005, $26,341-365$. [CrossRef]

12. Dean, J.; van Dooren, K.; Weinstein, P. Does Biodiversity Improve Mental Health in Urban Settings? Med. Hypotheses 2011, 76, 877-880. [CrossRef]

13. Carpenter, M. From 'Healthful Exercise' to 'Nature on Prescription': The Politics of Urban Green Spaces and Walking for Health. Landsc. Urban. Plan. 2013, 118, 120-127. [CrossRef]

14. Johnson, M.; Wood, A. Green Prescription Patient Survey 2015 Report; Ministry of Health: Singapore, $2015 ;$ p. 195.

15. Response for Nature. Response for Nature: England. 2015. Available online: http://ww2.rspb.org.uk/Images/ responsefornature_england_tcm9--407740.pdf (accessed on 2 November 2020).

16. Nutsford, D.; Pearson, A.L.; Kingham, S. An Ecological Study Investigating the Association between Access to Urban Green Space and Mental Health. Public Health 2013, 127, 1005-1011. [CrossRef]

17. van den Berg, M.; Wendel-Vos, W.; van Poppel, M.; Kemper, H.; van Mechelen, W.; Maas, J. Health Benefits of Green Spaces in the Living Environment: A Systematic Review of Epidemiological Studies. Urban. For. Urban. Green. 2015, 14, 806-816. [CrossRef]

18. Bodicoat, D.H.; O’Donovan, G.; Dalton, A.M.; Gray, L.J.; Yates, T.; Edwardson, C.; Hill, S.; Webb, D.R.; Khunti, K.; Davies, M.J.; et al. The Association between Neighbourhood Greenspace and Type 2 Diabetes in a Large Cross-Sectional Study. BMJ Open 2014, 4, e006076. [CrossRef] [PubMed]

19. Duncan, M.J.; Clarke, N.D.; Birch, S.L.; Tallis, J.; Hankey, J.; Bryant, E.; Eyre, E.L.J. The Effect of Green Exercise on Blood Pressure, Heart Rate and Mood State in Primary School Children. Int. J. Environ. Res. Public Health 2014, 11, 3678-3688. [CrossRef]

20. Markevych, I.; Thiering, E.; Fuertes, E.; Sugiri, D.; Berdel, D.; Koletzko, S.; von Berg, A.; Bauer, C.-P.; Heinrich, J. A Cross-Sectional Analysis of the Effects of Residential Greenness on Blood Pressure in 10-Year Old Children: Results from the GINIplus and LISAplus Studies. BMC Public Health 2014, 14, 477. [CrossRef] [PubMed]

21. Hanski, I.; von Hertzen, L.; Fyhrquist, N.; Koskinen, K.; Torppa, K.; Laatikainen, T.; Karisola, P.; Auvinen, P.; Paulin, L.; Mäkelä, M.J.; et al. Environmental Biodiversity, Human Microbiota, and Allergy Are Interrelated. Proc. Natl. Acad. Sci. USA 2012, 109, 8334-8339. [CrossRef] [PubMed]

22. Kardan, O.; Gozdyra, P.; Misic, B.; Moola, F.; Palmer, L.J.; Paus, T.; Berman, M.G. Neighborhood Greenspace and Health in a Large Urban Center. Sci. Rep. 2015, 5, 11610. [CrossRef]

23. Seresinhe, C.I.; Preis, T.; Moat, H.S. Quantifying the Impact of Scenic Environments on Health. Sci. Rep. 2015, 5, 16899. [CrossRef]

24. Antonelli, M.; Barbieri, G.; Donelli, D. Effects of Forest Bathing (Shinrin-Yoku) on Levels of Cortisol as a Stress Biomarker: A Systematic Review and Meta-Analysis. Int. J. Biometeorol. 2019, 63, 1117-1134. [CrossRef]

25. Barton, J.; Pretty, J. What Is the Best Dose of Nature and Green Exercise for Improving Mental Health? A Multi-Study Analysis. Environ. Sci. Technol. 2010, 44, 3947-3955. [CrossRef]

26. Dallimer, M.; Irvine, K.N.; Skinner, A.M.J.; Davies, Z.G.; Rouquette, J.R.; Maltby, L.L.; Warren, P.H.; Armsworth, P.R.; Gaston, K.J. Biodiversity and the Feel-Good Factor: Understanding Associations between Self-Reported Human Well-Being and Species Richness. BioScience 2012, 62, 47-55. [CrossRef]

27. Ojala, A.; Korpela, K.; Tyrväinen, L.; Tiittanen, P.; Lanki, T. Restorative Effects of Urban Green Environments and the Role of Urban-Nature Orientedness and Noise Sensitivity: A Field Experiment. Health Place 2019, 55, 59-70. [CrossRef]

28. Mitchell, R.; Popham, F. Effect of Exposure to Natural Environment on Health Inequalities: An Observational Population Study. Lancet 2008, 372, 1655-1660. [CrossRef]

29. Shanahan, D.F.; Bush, R.; Gaston, K.J.; Lin, B.B.; Dean, J.; Barber, E.; Fuller, R.A. Health Benefits from Nature Experiences Depend on Dose. Sci. Rep. 2016, 6, 28551. [CrossRef]

30. Cox, D.T.C.; Shanahan, D.F.; Hudson, H.L.; Fuller, R.A.; Anderson, K.; Hancock, S.; Gaston, K.J. Doses of Nearby Nature Simultaneously Associated with Multiple Health Benefits. Int. J. Environ. Res. Public Health 2017, 14, 172. [CrossRef] [PubMed]

31. Renalds, A.; Smith, T.H.; Hale, P.J. A Systematic Review of Built Environment and Health. Fam. Community Health 2010, 33, 68-78. [CrossRef] [PubMed]

32. Bentley, R.; Blakely, T.; Kavanagh, A.; Aitken, Z.; King, T.; McElwee, P.; Giles-Corti, B.; Turrell, G. A Longitudinal Study Examining Changes in Street Connectivity, Land Use, and Density of Dwellings and Walking for Transport in Brisbane, Australia. Environ. Health Perspect 2018, 126, 57003. [CrossRef] [PubMed]

33. Panter, J.; Mytton, O.; Sharp, S.; Brage, S.; Cummins, S.; Laverty, A.A.; Wijndaele, K.; Ogilvie, D. Using Alternatives to the Car and Risk of All-Cause, Cardiovascular and Cancer Mortality. Heart 2018, 104, 1749-1755. [CrossRef] [PubMed]

34. Chandrabose, M.; Owen, N.; Giles-Corti, B.; Turrell, G.; Carver, A.; Sugiyama, T. Urban Densification and 12-Year Changes in Cardiovascular Risk Markers. J. Am. Heart Assoc. 2019, 8. [CrossRef]

35. Chandrabose, M.; Rachele, J.N.; Gunn, L.; Kavanagh, A.; Owen, N.; Turrell, G.; Giles-Corti, B.; Sugiyama, T. Built Environment and Cardio-Metabolic Health: Systematic Review and Meta-Analysis of Longitudinal Studies. Obes. Rev. 2019, 20, 41-54. [CrossRef]

36. Glazier, R.H.; Creatore, M.I.; Weyman, J.T.; Fazli, G.; Matheson, F.I.; Gozdyra, P.; Moineddin, R.; Shriqui, V.K.; Booth, G.L. Density, Destinations or Both? A Comparison of Measures of Walkability in Relation to Transportation Behaviors, Obesity and Diabetes in Toronto, Canada. PLoS ONE 2014, 9, e85295. [CrossRef]

37. Rundle, A.; Roux, A.V.D.; Freeman, L.M.; Miller, D.; Neckerman, K.M.; Weiss, C.C. The Urban Built Environment and Obesity in New York City: A Multilevel Analysis. Am. J. Health Promot 2007, 21, 326-334. [CrossRef] [PubMed] 
38. March, D.; Hatch, S.L.; Morgan, C.; Kirkbride, J.B.; Bresnahan, M.; Fearon, P.; Susser, E. Psychosis and Place. Epidemiol. Rev. 2008, 30, 84-100. [CrossRef] [PubMed]

39. Richards, D.R.; Passy, P.; Oh, R.R.Y. Impacts of Population Density and Wealth on the Quantity and Structure of Urban Green Space in Tropical Southeast Asia. Landsc. Urban. Plan. 2017, 157, 553-560. [CrossRef]

40. Fan, P.; Wan, G.; Xu, L.; Park, H.; Xie, Y.; Liu, Y.; Yue, W.; Chen, J. Walkability in Urban Landscapes: A Comparative Study of Four Large Cities in China. Landsc. Ecol. 2018, 33, 323-340. [CrossRef]

41. Kottek, M.; Grieser, J.; Beck, C.; Rudolf, B.; Rubel, F. World Map of the Köppen-Geiger Climate Classification Updated. Meteorologische Zeitschrift 2006, 15, 259-263. [CrossRef]

42. Data Europa EU GHS-POP R2015A-GHS Population Grid, Derived from GPW4, Multitemporal (1975, 1990, 2000, 2015)-Data Europa EU 2015. Available online: https:/ / data.europa.eu/data / datasets/jrc-ghsl-ghs_pop_gpw4_globe_r2015a?locale=en (accessed on 17 August 2021).

43. Abdul Aziz, N.A.; Konijnendijk van den Bosch, C.; Nilsson, K. Recreational Use of Urban Green Space in Malaysian Cities. Int. J. Bus. Soc. 2018, 19, 1-16.

44. Priego, C.; Breuste, J.; Rojas, J. Perception and Value of Nature in Urban Landscapes: A Comparative Analysis of Cities in Germany, Chile and Spain. Landsc. Online 2008, 7, 1-22. [CrossRef]

45. Tam, K.-P. Concepts and Measures Related to Connection to Nature: Similarities and Differences. J. Environ. Psychol. 2013, 34, 64-78. [CrossRef]

46. Shanahan, D.F.; Fuller, R.A.; Bush, R.; Lin, B.B.; Gaston, K.J. The Health Benefits of Urban Nature: How Much Do We Need? BioScience 2015, 65, 476-485. [CrossRef]

47. Kuo, M. How Might Contact with Nature Promote Human Health? Promising Mechanisms and a Possible Central Pathway. Front. Psychol. 2015, 6, 1093. [CrossRef] [PubMed]

48. Government of Singapore Total Land Area of Singapore. Available online: https://data.gov.sg/dataset/total-land-area-ofsingapore (accessed on 31 August 2021).

49. Singapore Department of Statistics. Population and Population Structure-Latest Data; Singapore Department of Statistics: Singapore, 2019.

50. Angel, S. Atlas of Urban Expansion: The 2016 Edition, Volume 1: Areas and Densities; New York University: New York, NY, USA, 2016; Volume 1, p. 500.

51. Schwarz, N.; Oyserman, D. Asking Questions about Behavior: Cognition, Communication, and Questionnaire Construction. Am. J. Eval. 2001, 22, 127-160. [CrossRef]

52. Fontana, S.; Sattler, T.; Bontadina, F.; Moretti, M. How to Manage the Urban Green to Improve Bird Diversity and Community Structure. Landsc. Urban. Plan. 2011, 101, 278-285. [CrossRef]

53. Gao, T.; Hedblom, M.; Emilsson, T.; Nielsen, A.B. The Role of Forest Stand Structure as Biodiversity Indicator. For. Ecol. Manag. 2014, 330, 82-93. [CrossRef]

54. Threlfall, C.G.; Williams, N.S.G.; Hahs, A.K.; Livesley, S.J. Approaches to Urban Vegetation Management and the Impacts on Urban Bird and Bat Assemblages. Landsc. Urban. Plan. 2016, 153, 28-39. [CrossRef]

55. Astell-Burt, T.; Feng, X. Association of Urban Green Space With Mental Health and General Health Among Adults in Australia. Jama Netw. Open 2019, 2, e198209. [CrossRef] [PubMed]

56. Urban Redevelopment Authority. Singapore Master Plan 2019. Available online: https: / /www.ura.gov.sg/maps / ?service=MP (accessed on 31 March 2021).

57. Gaw, L.Y.-F.; Yee, A.T.K.; Richards, D.R. A High-Resolution Map of Singapore's Terrestrial Ecosystems. Data 2019,4 , 116. [CrossRef]

58. Chong, K.Y.; Teo, S.; Kurukulasuriya, B.; Chung, Y.F.; Rajathurai, S.; Tan, H.T.W. Not All Green Is as Good: Different Effects of the Natural and Cultivated Components of Urban Vegetation on Bird and Butterfly Diversity. Biol. Conserv. 2014, 171, 299-309. [CrossRef]

59. Lovibond, S.H.; Lovibond, P.F. Manual for the Depression Anxiety Stress Scales-DASS21 Response Form; Psychology Foundation: Sydney, Australia, 1996; pp. 335-343.

60. Maas, J.; Verheij, R.A.; Groenewegen, P.P.; de Vries, S.; Spreeuwenberg, P. Green Space, Urbanity, and Health: How Strong Is the Relation? J. Epidemiol. Community Health 2006, 60, 587-592. [CrossRef]

61. Mitchell, R.J.; Richardson, E.A.; Shortt, N.K.; Pearce, J.R. Neighborhood Environments and Socioeconomic Inequalities in Mental Well-Being. Am. J. Prev. Med. 2015, 49, 80-84. [CrossRef]

62. White, M.P.; Alcock, I.; Grellier, J.; Wheeler, B.W.; Hartig, T.; Warber, S.L.; Bone, A.; Depledge, M.H.; Fleming, L.E. Spending at Least 120 Minutes a Week in Nature Is Associated with Good Health and Wellbeing. Sci. Rep. 2019, 9, 7730. [CrossRef] [PubMed]

63. Oh, R.Y.R.; Fielding, K.S.; Nghiem, T.P.L.; Chang, C.-C.; Shanahan, D.F.; Gaston, K.J.; Carrasco, R.L.; Fuller, R.A. Factors Influencing Nature Interactions Vary between Cities and Types of Nature Interactions. People Nat. 2021, 3, 405-417. [CrossRef]

64. Nisbet, E.K.; Zelenski, J.M.; Murphy, S.A. The Nature Relatedness Scale: Linking Individuals' Connection With Nature to Environmental Concern and Behavior. Environ. Behav. 2009, 41, 715-740. [CrossRef]

65. R Development Core Team. R: A Language and Environment for Statistical Computing; R Foundation for Statistical Computing: Vienna, Austria, 2019. 
66. Christensen, R.H.B. Cumulative Link Models for Ordinal Regression with the R Package Ordinal. J. Stat. Softw. 2018, 40. submitted.

67. Christensen, R.H.B. A Tutorial on FItting Cumulative Link Mixed Models with Clmm2 from the Ordinal Package. Available online: https://cran.r-project.org/web/packages/ordinal/vignettes/clmm2_tutorial.pdf (accessed on 7 August 2020).

68. John, F.; Sanford, W.; Brad, P. Package 'Car' 2021. Available online: https://cran.r-project.org/web/packages/car/car.pdf (accessed on 9 July 2021).

69. Ripley, B.; Venables, B.; Bates, D.M.; Hornik, K.; Gebhardt, A.; Firth, D.; Ripley, M.B. Package 'Mass'; Version 7.3. 2013. Available online: http:/ /www2.uaem.mx/r-mirror/web/packages/MASS/ (accessed on 12 October 2020).

70. Singapore Strategy. Group Population In Brief; 2018. Available online: https://www.strategygroup.gov.sg/media--centre/ publications/population--in--brief (accessed on 31 March 2021).

71. Ratcliffe, E. Toward a Better Understanding of Pleasant Sounds and Soundscapes in Urban Settings. Cities Health 2021, 5, 82-85. [CrossRef]

72. Soga, M.; Gaston, K.J. The Ecology of Human-Nature Interactions. Proc. R. Soc. B Biol. Sci. 2020, 287, 20191882. [CrossRef] [PubMed]

73. Franco, L.S.; Shanahan, D.F.; Fuller, R.A. A Review of the Benefits of Nature Experiences: More Than Meets the Eye. Int. J. Environ. Res. Public Health 2017, 14, 864. [CrossRef] [PubMed]

74. Astell-Burt, T.; Feng, X.; Kolt, G.S. Green Space Is Associated with Walking and Moderate-to-Vigorous Physical Activity (MVPA) in Middle-to-Older-Aged Adults: Findings from 203883 Australians in the 45 and Up Study. Br. J. Sports Med. 2014, 48, 404-406. [CrossRef]

75. WHO Regional Office for Europe. Urban. Green Spaces and Health: A Review of Evidence; WHO Regional Office for Europe: Copenhagen, Denmark, 2016.

76. Pretty, J.; Peacock, J.; Sellens, M.; Griffin, M. The Mental and Physical Health Outcomes of Green Exercise. Int. J. Environ. Health Res. 2005, 15, 319-337. [CrossRef]

77. Maas, J.; van Dillen, S.M.E.; Verheij, R.A.; Groenewegen, P.P. Social Contacts as a Possible Mechanism behind the Relation between Green Space and Health. Health Place 2009, 15, 586-595. [CrossRef]

78. Ward-Smith, C.; Naidoo, T.; Olvitt, L.; Akhurst, J. Perceived Benefits of Nature-Based Experiences as Mediators of Connectedness with Nature: The Case of Mystic Mountain. South. Afr. J. Psychol. 2020, 50, 553-564. [CrossRef]

79. Bowler, D. The Importance of Nature for Health: Is There a Specific Benefit of Contact with Green Space? Syst. Rev. Collab. Environ. Evid. 2010, 40, 1-57.

80. Martyn, P.; Brymer, E. The Relationship between Nature Relatedness and Anxiety. J. Health Psychol. 2016, 21, 1436-1445. [CrossRef]

81. Capaldi, C.A.; Dopko, R.L.; Zelenski, J.M. The Relationship between Nature Connectedness and Happiness: A Meta-Analysis. Front. Psychol. 2014, 5. [CrossRef] [PubMed]

82. Zelenski, J.M.; Nisbet, E.K. Happiness and Feeling Connected: The Distinct Role of Nature Relatedness. Environ. Behav. 2014, 46, 3-23. [CrossRef]

83. Mayer, F.S.; Frantz, C.M.; Bruehlman-Senecal, E.; Dolliver, K. Why Is Nature Beneficial?: The Role of Connectedness to Nature. Environ. Behav. 2009, 41, 607-643. [CrossRef]

84. Bang, M.; Medin, D.L.; Atran, S. Cultural Mosaics and Mental Models of Nature. Proc. Natl. Acad. Sci. USA 2007, 104, 13868-13874 [CrossRef]

85. Bell, S.L.; Phoenix, C.; Lovell, R.; Wheeler, B.W. Green Space, Health and Wellbeing: Making Space for Individual Agency. Health Place 2014, 30, 287-292. [CrossRef]

86. Beatley, T. Singapore: How to Grow a High-Rise City in a Garden. SiteLINES J. Place 2012, 8, 14-17.

87. Tan, P.Y.; Wang, J.; Sia, A. Perspectives on Five Decades of the Urban Greening of Singapore. Cities 2013, 32, 24-32. [CrossRef]

88. Lawton, E.; Brymer, E.; Clough, P.; Denovan, A. The Relationship between the Physical Activity Environment, Nature Relatedness, Anxiety, and the Psychological Well-Being Benefits of Regular Exercisers. Front. Psychol. 2017, 8, 1058. [CrossRef] [PubMed]

89. Bixler, R.D.; Floyd, M.F. Nature Is Scary, Disgusting, and Uncomfortable. Environ. Behav. 1997, 29, 443-467. [CrossRef]

90. Stults-Kolehmainen, M.A.; Sinha, R. The Effects of Stress on Physical Activity and Exercise. Sports Med. 2014, 44, 81-121. [CrossRef] [PubMed]

91. Difrancesco, S.; Lamers, F.; Riese, H.; Merikangas, K.R.; Beekman, A.T.F.; van Hemert, A.M.; Schoevers, R.A.; Penninx, B.W.J.H. Sleep, Circadian Rhythm, and Physical Activity Patterns in Depressive and Anxiety Disorders: A 2-Week Ambulatory Assessment Study. Depress. Anxiety 2019, 36, 975-986. [CrossRef]

92. de Vries, S.; van Dillen, S.M.E.; Groenewegen, P.P.; Spreeuwenberg, P. Streetscape Greenery and Health: Stress, Social Cohesion and Physical Activity as Mediators. Soc. Sci. Med. 2013, 94, 26-33. [CrossRef]

93. Wolf, L.J.; Ermgassen, S.Z.; Balmford, A.; White, M.; Weinstein, N. Is Variety the Spice of Life? An Experimental Investigation into the Effects of Species Richness on Self-Reported Mental Well-Being. PLoS ONE 2017, 12, e0170225. [CrossRef]

94. Marselle, M.R.; Martens, D.; Dallimer, M.; Irvine, K.N. Review of the Mental Health and Well-being Benefits of Biodiversity. In Biodiversity and Health in the Face of Climate Change; Marselle, M.R., Stadler, J., Korn, H., Irvine, K.N., Bonn, A., Eds.; Springer International Publishing: Cham, Germany, 2019; pp. 175-211. ISBN 978-3-030-02318-8.

95. Fuller, R.A.; Irvine, K.N.; Devine-Wright, P.; Warren, P.H.; Gaston, K.J. Psychological Benefits of Greenspace Increase with Biodiversity. Biol. Lett. 2007, 3, 390-394. [CrossRef] 
96. Luck, G.W.; Davidson, P.; Boxall, D.; Smallbone, L. Relations between Urban Bird and Plant Communities and Human Well-Being and Connection to Nature. Conserv. Biol. 2011, 25, 816-826. [CrossRef]

97. Nghiem, L.T.P.; Zhang, Y.; Oh, R.R.Y.; Chang, C.; Tan, C.L.Y.; Shannahan, D.F.; Lin, B.B.; Gaston, K.J.; Fuller, R.A.; Carrasco, L.R. Equity in Green and Blue Spaces Availability in Singapore. Landsc. Urban. Plan. 2021, 210, 104083. [CrossRef]

98. Ode, Å.; Hagerhall, C.M.; Sang, N. Analysing Visual Landscape Complexity: Theory and Application. Landsc. Res. 2010, 35, 111-131. [CrossRef]

99. de Vries, S.; Snep, R. Biodiversity in the Context of 'Biodiversity-Mental Health' Research. In Biodiversity and Health in the Face of Climate Change; Marselle, M.R., Stadler, J., Korn, H., Irvine, K.N., Bonn, A., Eds.; Springer International Publishing: Cham, Germany, 2019; pp. 159-173. ISBN 978-3-030-02318-8.

100. Austen, G.E.; Dallimer, M.; Irvine, K.N.; Maund, P.R.; Fish, R.D.; Davies, Z.G. Exploring Shared Public Perspectives on Biodiversity Attributes. People Nat. 2021, 3, 901-913. [CrossRef]

101. Doherty, S.T.; Lemieux, C.J.; Canally, C. Tracking Human Activity and Well-Being in Natural Environments Using Wearable Sensors and Experience Sampling. Soc. Sci. Med. 2014, 106, 83-92. [CrossRef]

102. Cooper, A.R.; Page, A.S.; Wheeler, B.W.; Hillsdon, M.; Griew, P.; Jago, R. Patterns of GPS Measured Time Outdoors after School and Objective Physical Activity in English Children: The PEACH Project. Int. J. Behav. Nutr. Phys. Act. 2010, 7, 31. [CrossRef] [PubMed]

103. Soga, M.; Gaston, K.J.; Yamaura, Y. Gardening Is Beneficial for Health: A Meta-Analysis. Prev. Med. Rep. 2017, 5, 92-99. [CrossRef]

104. Hu, F.B. Globalization of Diabetes: The Role of Diet, Lifestyle, and Genes. Diabetes Care 2011, 34, 1249-1257. [CrossRef] [PubMed]

105. Hu, F.B.; Solomon, C.G. Diet, Lifestyle, and the Risk of Type 2 Diabetes Mellitus in Women. N. Engl. J. Med. 2001, 345, 790-797. [CrossRef] [PubMed]

106. Colagiuri, S.; Vita, P.; Cardona-Morrell, M.; Singh, M.F.; Farrell, L.; Milat, A.; Haas, M.; Bauman, A. The Sydney Diabetes Prevention Program: A Community-Based Translational Study. BMC Public Health 2010, 10, 328. [CrossRef]

107. Giles-Corti, B.; Broomhall, M.H.; Knuiman, M.; Collins, C.; Douglas, K.; Ng, K.; Lange, A.; Donovan, R.J. Increasing Walking. Am. J. Prev. Med. 2005, 28, 169-176. [CrossRef]

108. Astell-Burt, T.; Feng, X.; Kolt, G.S. Mental Health Benefits of Neighbourhood Green Space Are Stronger among Physically Active Adults in Middle-to-Older Age: Evidence from 260,061 Australians. Prev. Med. 2013, 57, 601-606. [CrossRef]

109. Astell-Burt, T.; Feng, X.; Kolt, G.S. Greener Neighborhoods, Slimmer People? Evidence from 246920 Australians. Int. J. Obes 2014, 38, 156-159. [CrossRef] [PubMed]

110. Astell-Burt, T.; Feng, X.; Kolt, G.S. Is Neighborhood Green Space Associated With a Lower Risk of Type 2 Diabetes? Evidence From 267,072 Australians. Diabetes Care 2014, 37, 197-201. [CrossRef]

111. Gupta, S.S.; Teede, H.; Aroni, R. Spicing up Your Advice for South Asian and Anglo-Australians with Type 2 Diabetes and CVD: Do Cultural Constructions of Diet Matter? Appetite 2018, 120, 679-697. [CrossRef]

112. Brown, C.D.; Higgins, M.; Donato, K.A.; Rohde, F.C.; Garrison, R.; Obarzanek, E.; Ernst, N.D.; Horan, M. Body Mass Index and the Prevalence of Hypertension and Dyslipidemia. Obes. Res. 2000, 8, 605-619. [CrossRef]

113. Drøyvold, W.B.; Midthjell, K.; Nilsen, T.I.L.; Holmen, J. Change in Body Mass Index and Its Impact on Blood Pressure: A Prospective Population Study. Int. J. Obes 2005, 29, 650-655. [CrossRef]

114. Flores-Huerta, S.; Klünder-Klünder, M.; Reyes de la Cruz, L.; Santos, J.I. Increase in Body Mass Index and Waist Circumference Is Associated with High Blood Pressure in Children and Adolescents in Mexico City. Arch. Med. Res. 2009, 40, 208-215. [CrossRef] [PubMed]

115. Tebar, W.R.; Ritti-Dias, R.M.; Farah, B.Q.; Zanuto, E.F.; Vanderlei, L.C.M.; Christofaro, D.G.D. High Blood Pressure and Its Relationship to Adiposity in a School-Aged Population: Body Mass Index vs Waist Circumference. Hypertens Res. 2018, 41, 135-140. [CrossRef] [PubMed]

116. Tsunetsugu, Y.; Lee, J.; Park, B.-J.; Tyrväinen, L.; Kagawa, T.; Miyazaki, Y. Physiological and Psychological Effects of Viewing Urban Forest Landscapes Assessed by Multiple Measurements. Landsc. Urban. Plan. 2013, 113, 90-93. [CrossRef]

117. Lee, J.; Tsunetsugu, Y.; Takayama, N.; Park, B.-J.; Li, Q.; Song, C.; Komatsu, M.; Ikei, H.; Tyrväinen, L.; Kagawa, T.; et al. Influence of Forest Therapy on Cardiovascular Relaxation in Young Adults. Evid. Based Complementary Altern. Med. 2014, 2014 , e834360. [CrossRef]

118. Song, C.; Ikei, H.; Igarashi, M.; Miwa, M.; Takagaki, M.; Miyazaki, Y. Physiological and Psychological Responses of Young Males during Spring-Time Walks in Urban Parks. J. Physiol. Anthropol. 2014, 33, 8. [CrossRef] [PubMed]

119. Beagley, J.; Guariguata, L.; Weil, C.; Motala, A.A. Global Estimates of Undiagnosed Diabetes in Adults. Diabetes Res. Clin. Pract. 2014, 103, 150-160. [CrossRef] [PubMed]

120. Tatiana, N.; Sug (Sarah) Yoon, S.; Vicki, B.; Qiuping, G. Hypertension Among Adults in the United States: National Health and Nutrition Examination Survey, 2011-2012; U.S. Department of Health and Human Services; Centers for Disease Control and Prevention; National Center for Health Statistics: Hyattsville, MA, USA, 2013. 